\title{
MEDICINE AND IDEOLOGY: THE METHODOLOGY AND EPISTEMOLOGY OF THE SENSATIONALISTS
}

Eighteenth-century European intellectuals generally assumed that they were living in a time of fundamental change. They were convinced that intellectual, material, and social progress was possible, that it was occurring in at least some places, and that it was bound to continue. The future must be more enlightened, more free, more tolerant, and more prosperous than the past. Even when they risked imprisonment, vilification, and exile because they disparaged established institutions and attitudes, they did so believing that their notions would finally prevail. It is difficult for us to recreate their optimism. To a large extent, our own cynicism about the present and unease about the future are due to society's failure to realize the philosophes' vision Earlier utopian aspirations had been rooted in a Christian ideal and looked towards man's spiritual and moral nature for their realization. The forward-looking man in the eighteenth century, however, believed that a better future would derive from the study of the natural world and of man's place in it. Provided that the study was conducted correctly, man would come to understand both his inner nature and his environment, and be enabled thereby to live harmoniously in the world. In a profound sense, the eighteenth-century savants believed in the virtue of a scientific, technological, and hence materialistic future. These themes have long preoccupied students of the Enlightenment and many persons have written about them at length. My primary interest here is in the way in which this notion of possible and desirable progress affected certain scientists and especially physicians and writers on physiology.

During the eighteenth century, there was a growing sense of the relative backwardness of the life sciences, especially when their achievements were measured against those of physics and chemistry. In the attempt to promote the advancement of medicine, the state intervened, meanwhile offending the hide-bound Paris Medical Faculty, long-time enemies of innovation who sensed their traditional power slipping from them. A Société Royale de Médecine was established by royal patent in 1776 as an agency of the French state, to be consulted by members of the administration. Its mandate was to address questions surrounding human and animal epidemics, sanitary conditions, endemic and occupational diseases, surgical and anatomical subjects, and the supervision of therapeutic mineral waters. It quickly became a haven for the young progressive spirits of French medicine so that, apart from some 162 associate members, it attracted thousands of corresponding members from throughout the kingdom. It was closed in 1793 as an institution of the Ancien Régime. Nevertheless, its members were to contribute much to the medical world of post-revolutionary France as well, bringing to fruition then many of the ideas which had been born before the great iconoclasm.

Although the Société Royale's perpetual secretary, Félix Vicq d'Azyr (1748-94) did not survive the Revolution, many of his ideas found a home in the newly created Écoles 


\section{Medicine and ideology}

de Santé. Remembered especially as a comparative anatomist, he was also much preoccupied with questions of scientific method and direction. He declared that medicine needed to be incorporated into a larger "science of man", one that concerned itself not only with man's physical being but also with his psychological and social make-up. The discussion of just such an integrated science was taken up widely after the Revolution, as we shall see later in this chapter. ${ }^{1}$ The Société Royale's optimistic reforming drive and its members' advocacy of a larger "science of man" persisted, finding a good home in the Société Médicale d'Émulation. Bichat, one of its founding members, wrote the 'Preliminary discourse' to the first volume of the Mémoires de la Société Médicale d'Émulation, claiming that "the modest reunion of several young friends of the sciences scares some grave persons who appear to suspect there a secretly hatched conspiracy against their antiquated principles and the ruinous state of their doctrine." In a less than conciliatory vein, he said that he hoped that their detractors would abandon envy for reason but, perhaps more importantly, that medicine would be incorporated into a general "science of man". Meanwhile, he invoked Hippocrates as the eternal model to be emulated. ${ }^{2}$

The original membership list of the Société d'Émulation included many of the most famous physicians of the time, many of them former members of the Sociéte Royale. If asked about the philosophy or methodology with which they approached their work, most, if not all, would have claimed to be sensationalists and Newtonians. By that, they would have meant that they undertook to apply to their own work the methods that the great physicist had used in his. The imitation of physics understandably preoccupied many savants, so that the intellectual and scientific world of the eighteenth century was crowded with would-be Newtonians of every conceivable discipline, including theology. Sensationalism was the psychological system, the epistemological theory that, in the estimation of many, accompanied Newtonian theory and provided the theoretical framework for progressive scientific procedure.

Sensationalist theory was rooted in the conviction that learning and knowledge proceed from the five senses and not from some innate pool of ideas. As with many ideas on biological subjects, Aristotle seems to have achieved priority by stating that all knowledge derives from the senses. French sensationalists, however, including most of the members of the Société d'Émulation, traced their ideas on the subject to the Abbé Étienne de Condillac in the 1750s, who, in turn, owed much to John Locke (1632-1704). Locke discussed certain general precepts basic to scientific investigation, which corresponded to Newtonian method and procedure. In 1801, Destutt de Tracy, one of the foremost exponents of sensationalist philosophy, dubbed the system "ideology", and its French proponents came to be generally known as "ideologues".

\footnotetext{
1 Caroline C. Hannaway. 'The Société Royale de Médecine and epidemics in the ancien régime', Bull. Hist. Med., 1972, 46: 257-273. Charles Coulton Gillispie, Science and polity in France at the end of the old regime, Princeton University Press, 1980, pp. 194-226. Caroline C. Hannaway, Medicine, public welfare and the state in eighteenth-century France: the Sociéte Royal de Médecine, Paris (1776-93), PhD thesis, Johns Hopkins University, 1974; Ann Arbor, Mich., University Microfilms, 1976.

${ }^{2}$ Xavier Bichat, 'Discours préliminaire', Mémoires de la Société Médicale d'Émulation, 1796, 7: i-xii. For a discussion of the philosophy of the society and especially of its members' views concerning the nature of scientific medicine, see Sergio Moravia, 'Philosophie et médecine en France à la fin du XVIII'siècle', Studies on Voltaire and the eighteenth century, 1972, 89: 1089-1151.
} 


\section{Xavier Bichat}

By the end of the eighteenth century, "ideology" had become very influential in France. The way in which physicians in particular interpreted ideology and adapted it is our primary concern in this chapter. The way in which Bichat's work was influenced by sensationalist precepts should become clear in succeeding chapters.

To early seventeenth-century philosophers and scientists, it seemed that philosophical knowledge is attainable if one proceeds from some original certainty. They presumed that one can correctly deduce all propositions from an initial axiom, so long as it is sound and one proceeds rigorously. Descartes was the most notable spokesman for that position. By the end of the century, this approach seemed much less credible. Newton, for example, took care to affirm that to do his work, he had proceeded not from axioms but from the data of experience and experiment. He elevated the status of data so acquired to a supreme position in science. He also limited the scientists' domain by contending that speculation about metaphysical and theological questions was outside their competence: that is, Newton's approach to nature was inductive. Whereas Descartes' statement of certainty, his "I think, therefore I am", had been his starting-point, Newton's statement of the law of universal gravitation and his formulations about optics were the end-point of his work. ${ }^{3}$

At the end of the seventeenth century, John Locke set out to create a science of the human mind on the basis of Newton's principles. In the words of Jean d'Alembert in the 'Preliminary discourse' to the Encyclopédie, "Locke reduced metaphysics to what may be, in effect, the experimental physics of the soul". "To do so, he attempted to trace the natural history of human ideas to their simplest form in the consciousness. Locke contended that, lacking innate ideas, the mind is as "white paper, void of all characters, without any ideas". All man's complex mental operations, his reason and knowledge, are the product of the interaction of his sensations and of an innate capacity for reflection. Our senses convey some distinct perceptions into the mind, giving us our ideas of such things as "yellow, white, heat, cold, hard, bitter, sweet, and all those which we call sensible qualities". The reflective capacity of the mind or the soul is a kind of internal sense by means of which we develop "perception, thinking, doubting, believing, reasoning, knowing, willing and all the different actings of our own minds". Acting together, these supply all the material necessary for thought. "These two, I say, viz, external material things, as the objects of SENSATION and the operations of our own minds within, as the objects of REFLECTION, are to me

\footnotetext{
${ }^{3}$ There are a number of good studies of Newtonianism in the seventeenth and eighteenth centuries. Charles Coulton Gillispie's lively and elegant essay 'Science and the Enlightenment', The edge of objectivity, Princeton University Press, 1959, pp. 151-202, remains the first work which ought to be consulted on the topic. Some of the more recent important works are Robert E. Schofield, Mechanism and materialism. British natural philosophy in an age of reason, Princeton University Press, 1970; Arnold Thackray, Atoms and powers, Cambridge, Mass., Harvard University Press, 1970; T. M. Brown, "The mechanical philosophy and the "Animal oeconomy",' Princeton University PhD thesis, 1970; Georges Gusdorf, Les principes de la pensée au siècle des lumières, Paris, Payot, 1971, especially 'L'intelligibilité au $\mathrm{XVIII}^{\mathrm{C}}$ siècle', pp. 151-289; and finally, the classic work of Ernst Cassirer. The philosophy of the enlightenment, trans. by Fritz C. A. Koelin and James P. Pettegrove, 7th ed., Princeton University Press, 1965 , pp. 3-36. Gusdorf in particular has examined the importance of this English philosophy and its effects
upon French science. 4 Jean La Rond d'Alembert, Preliminary discourse to the Encyclopedia of Diderot, trans. by Richard
Schwab, Indianapolis, Bobbs-Merrill, 1963.
} 


\section{Medicine and ideology}

the only originals from whence all our ideas take their beginnings."'s

The Newtonian and Lockian systems took rather a long time to be assimilated in France, for they collided for a time with a patriotically based allegiance to Cartesianism. Indeed, the Cartesian Fontenelle dominated the powerful Académie des Sciences for years, thus discouraging the diffusion of alternate views. Voltaire first assisted the importation of English ideas into France when he cited Locke's views approvingly in his widely read Lettre sur les anglais of 1734 . He became a powerful propagandist on Newton's behalf, arguing that Descartes had erred fundamentally when he tried to create a physics without reference to experiment. ${ }^{6}$ Voltaire's immensely successful Élements de la philosophie de Newton of 1738 was a particularly decisive blow to a Cartesianism that had become something of an albatross. The Lockianism that accompanied Newtonian theory seemed to provide the very conceptual tools which the French needed at the time, and they grasped them eagerly.

The Abbé Étienne Bonnot de Condillac (1714-1800) was the first person to develop Locke's theory. He eliminated the sensation-reflection dualism, contending that reflection, like all other faculties, is subordinate to sensation, which is the body's only source of cognition and intellectual activity. It was a bold step insofar as it eliminated any need for a hypothetical pool of innate ideas or for a divine origin for rational thought. Condillac also propounded in detail a method of scientific investigation known as "analysis", which was supposed to be the inductive method of Newton. In time, scientists and philosophers came to see the analytic procedure as the indispensable element of all labour of the mind. The political, moral, and biological applications of Condillac's work were to preoccupy many French thinkers, scientists, and politicians alike, until at least the post-revolutionary period. Its implications for medicine and physiology were examined and systematized in the writings of Tracy, Cabanis, and Pinel. Their work, in turn, strongly affected that of Bichat. The fundamental philosophy of Condillac, if not necessarily its details, was to be the reference point for all those persons who, like the members of the Société d'Émulation, wished to study the whole man in his psycho-physiological complexity.

The "philosopher of the philosophes", as Condillac was known, was an unusual man insofar as the Jesuits commended his work as much as did the materialists. A circumspect man and an ordained priest, he expressed the most potentially radical ideas in such a way that his lifelong loyalty to the Catholic faith never came into question. Étienne Bonnot took the name Condillac from the Château de Condillac which his father, a member of the petty nobility, had purchased in 1720. Condillac studied theology at the Sorbonne. Reserved, cold, and humourless, he knew the sophisticated salons of France, but did not shine in them. He became friends with Diderot and Rousseau in Paris while they were still all literary unknowns. ${ }^{7}$ In his Confessions, Rousseau related that it was Diderot who found a publisher for Condillac's first book,

\footnotetext{
' John Locke, An essay concerning human understanding, New York, Meridian, 1964, bk. II, ch. I, pp. 89-98.

' [François-Marie Arouet] Voltaire, 'Sur M. Locke', in Lettres sur les anglais, Cambridge University Press, 1931, pp. 45-51.

'Isabel F. Knight, The geometric spirit; the Abbe de Condillac and the French enlightenment, New Haven, Conn., Yale University Press, 1968, pp. 1-16.
} 


\section{Xavier Bichat}

his Essai sur l'origine des connaissances humaines of 1746. Meanwhile, he claimed for himself the distinction of being the first person to have appreciated Condillac's remarkable abilities. ${ }^{8}$

Condillac wrote the Essai sur l'origine, he claimed, to introduce Locke to the French public. By observing how sensations and impressions combine to produce knowledge and intelligence, he hoped to establish a philosophy of knowledge whose principles and procedures would in themselves constitute an exact science. ${ }^{9}$ Contending that all knowledge derives from sensory perception and that all complex perceptions are compounds of simple ideas, he imagined a newborn child to be but a passive recipient of a sudden multitude of confused sensations. In time, that which is first experienced as merely a bombardment of light and colour, discomfort and pleasure, motion and sound is developed into perception, consciousness, attention, memory, imagination, and contemplation. ${ }^{10}$

In 1754, he supplemented that work with the Traite des sensations, in which he specifically denied the existence of the reflective capacity which Locke had conjectured co-existed with sensation. He asserted that the psychic life and all its faculties and passions are developed from simple sensation alone.

To illustrate his thesis, Condillac described a hypothetical statue in which he could juggle the number and combination of the five senses. He began his examination of the process of learning by endowing it with smell, which he described as the least intellectual of all the senses. Since the statue, like man, is deprived of innate ideas, he wrote, the statue can know nothing except what it learns from odours. He undertook to show how, with smell, it would build up a knowledge of itself and of the world external to it, how it would develop its passions and complex abstract notions, and even how it would develop a notion of morality and of a deity. ${ }^{11}$ This use of a fictional statue as a kind of thought experiment was, at the time, a fairly common device. Buffon, for example, wishing to give an account of the development of human thought, extrapolated Locke's notions and speculated about a kind of "epistemological Adam". Confused initially by the bombardment of sensory impulses, the hypothetical first man learned eventually to distinguish ideas and to think. And in 1751, just three years before the appearance of the Traite des sensations, Diderot composed a Lettre sur les sourds et muets à l'usage de ceux qui entendent et qui parlent, in which he suggested the possibility of reconstructing the formation of

\footnotetext{
'The petulant and testy Rousseau took credit for Condillac's first success: "The booksellers of Paris are always arrogant and hard towards a new author, and metaphysics, which was not much in fashion at the time, did not offer a very attractive subject. I spoke of Condillac and his work to Diderot, and introduced them to each other. They were made to like each other and did so. Diderot induced Durant the bookseller to accept the Abbé's manuscript, and this great metaphysician received for his first book, and that almost as a favour, one hundred crowns and even that he would perhaps not have received but for me." Confessions of Jean-Jacques Rousseau, ed. by Lester G. Crocker, New York, Washington Square Press, 1956, bk. 7, pp. $171-172$.

'Étienne Bonnot de Condillac, ‘Essai sur l'origine des connaissances humaines', in Oeuvres complètes, 23 vols., Paris, Ch. Houel, 1798, vol. 1, pp. 1-16. See also the elegant work by Gerd Buchdahl, The image of Newton and Locke on the Age of Reason, London, Sheed \& Ward, 1961.

${ }^{10} \mathrm{Knight}$, op. cit., note 7 above, pp. 17-51. In this second chapter she examines the goals and the assumptions behind the Essai.

"See Condillac's 'Extrait raisonné', in 'Traité des sensations', Oeuvres complètes, op. cit., note 9 above, vol. 3, pp. 3-46.
} 


\section{Medicine and ideology}

human thought. In his particular thought experiment, Diderot imagined five persons, each in possession of a difference sense, relating their particular experiences and perspectives. ${ }^{12}$

How does Condillac's statue, possessing only the sense of smell, come to learn something of itself and of its world? A first odour strikes it and engages its attention. It experiences pleasure or discomfort depending upon the nature of that odour. When the statue encounters a second odour, its sensory capacity comes to be shared between memory of the first odour and attention to the present one. With a succession of odours, the statue learns to compare. If it attends to the odour of, say, a rose and a carnation, it perceives that there is a difference between them, from which comparison springs judgement. Eventually, to compare and to judge become a habit. Our statue was not surprised at the first sensation it encountered. It became capable of surprise only when it passed suddenly from an accustomed state to a new one. Surprise augments the activity of the operations of the soul, a word which Condillac used in the traditional sense to denote mind or consciousness.

As the soul compares past and present sensations, it develops a need which is felt as a privation of a desirable sensation. Our statue is capable of developing the faculty of imagination, which is really a more vivid form of memory. By now, our statue has developed a considerable number of faculties. Finally is born desire, which Condillac considered to be a major moving force behind human mental development. He described it as the faculties directing themselves to something for which one senses a need. To experience desire, a statue must be able to judge the difference between an existing state and a remembered one so as to be able to determine which is more acceptable. Thus are born the passions such as joy, suffering, need, desire, love, and hate. So far, however, the love is restricted to itself, for the statue is not yet aware of an external world. ${ }^{13}$

At this stage, Condillac continued, the statue should be capable of forming abstract ideas. Since the odour of each flower is particular, our statue will come to discern number from a succession of odours. It will learn of coming and going, of beginning and end, of past, present, and future. ${ }^{14} \mathrm{He}$ wrote that, "if we consider that to recall, compare, judge, discern, imagine, to be astonished, to have abstract ideas, and to have number and duration, to know general truths and particular ones are nothing but different ways of being attentive; that to have passions, to love, to hate, to hope, to fear and to want, are but different ways of desiring: and that finally to be attentive and to desire are really but to sense; we conclude that sensation encompasses all the faculties of the soul."1s

A statue possessing only the sense of hearing would develop similar faculties to the statue which could but smell. A statue in possession of two senses would acquire the same faculties extended further. The statue learns to perceive form with the eye only because of that organ's unique structure. It would do so with the nose also if the

\footnotetext{
12 Gusdorf, op. cit., note 3 above, pp. 232-249. Diderot's relationship with Condillac and with La Mettrie is discussed by J. H. Brumfitt, The French enlightenment, London, Macmillan, 1972, pp. 99-132.

${ }^{13}$ Condillac, op. cit., note 11 above, pp. 56-95.

14 Ibid., pp. 96-120.

15 Ibid., pp. $121-122$.
} 


\section{Xavier Bichat}

particles that produce the sense of smell travelled in straight lines, and if the nose were so constructed as to accept their input in parallel lines. Neither sight, nor smell, nor taste, nor hearing, however, will allow our statue to perceive that there exists a world external to itself. A sense of touch is essential to permit a living being to experience the existence of its own material body and therefore to learn that there are bodies besides itself in the world. ${ }^{16}$

Condillac believed that even the religious experience has a sensory foundation. The fact that the human race universally possesses the idea of God has long been the major argument for the existence of innate ideas. But Condillac believed that the religious sense comes once a human being learns that he is not alone in the world, and once he begins to sense his dependence. A child believes for a while that what is pleasing exists merely to please him and that which is disagreeable exists only to cause him pain. A prayer is born of the desire for whatever is favourable to his senses. Thus it is that primitive man, nearer to a childlike state than civilized man, addresses himself to the sun to urge it to shine and to the trees to urge them to bear fruit; he treats agents of pain and discomfort as disagreeable enemies to be appeased. And so the universe becomes populated with visible and invisible beings. The sophisticated mind proceeds from these first divinities to a more complex notion of first cause and thus to montheism. ${ }^{17}$

In the Traite des sensations, Condillac went on to discuss the analytic method, which derived from a sensationalist perception of the mind's functions. It has to do with comprehending complexity by dissociating the component elements of a thing so as to study them separately. By sorting out its parts, one imposes an order on to apparent chaos. ${ }^{18}$ In his Logique of 1780 , Condillac illustrated analysis with a country view. If we examine it merely as an attractive composite, we learn nothing substantial about it. To do that we must decompose it so as to examine its parts:

If [nature] gave us the faculty of seeing a multitude of things at once, it also gave us the faculty of looking at but one thing, that is to say, of directing our eyes to one only; and it is this faculty which is the result of our organization, which gives us all the knowledge which we can acquire by the use of sight .... Thus one begins with the principal objects: one observes them in succession and compares them to judge their connexions. When by this means, one has their respective situation, one observes in succession all those things in between them, or compares each of them with the nearest principal object and so determines their position. ${ }^{19}$

Thus it is that one comes to understand a countryside, universal gravitation, or the functioning of the human body. A resynthesis completes the analytic process. "We decompose only in order to recompose; and when knowledge is acquired, things,

16 Ibid., pp. 124-272.

17 Ibid., pp. 388-391. The question of how man acquires a knowledge of God is dealt with at somewhat greater length in Condillac's 'Traité des animaux', in Oeuvres complètes, op. cit., note 9 above, vol. 3, pp. 565-586.

${ }^{18}$ Condillac, op. cit., note 9 above, pp. 157-172. Analysis was described as the method appropriate to scientific inquiry by Isaac Newton, who wrote in the Opticks as follows: "We may proceed from compounds to ingrediants [sic] and from motion to the forces producing them, and in general from effects and their causes and from particular causes to more general ones, till the argument end in the most general. This is the method of analysis; and the synthesis consists in assuming the causes discovered and established as principles, and by then explaining the phenomena proceeding from them and proving the observations." Quoted by Buchdahl, op. cit., note 9 above, pp. 69-74.

${ }^{19}$ Condillac, 'Logique', in Oeuvres complètes, op. cit., note 9 above, vol. 22, pp. 16-20. 


\section{Medicine and ideology}

rather than being successive, have the same order in the mind that they have outside. Our knowledge consists in this order." 20 Condillac assumed that he had employed just such an analytic process, albeit imaginary, to demonstrate that all knowledge is sensory. But as Knight has pointed out, he is open to the criticism that he violated his own methodological principles because, instead of commencing a study with verifiable facts, he used a fictitious statue-man. ${ }^{21}$

In his Logique, Condillac addressed the subject of language, which he described as coinciding with analysis itself. Once again, he was taking up a theme popular in the Enlightenment. Many persons speculated about the nature of original language and its connexion with human consciousness. In 1752, for example, Maupertuis addressed a Lettre sur le progrès des sciences to Frederick II, proposing some experiments on, for example, two or three abandoned children to isolate them complete from the external world so as to observe their language development. A good example of the fruit born of Condillac's treatment of the subject is the achievement of Antoine Lavoisier, who assiduously studied his work and subsequently produced a linguistic as well as a methodological reform in chemistry. In the eighteenth century, of course, chemistry was rudimentary, lending itself to analysis because it was concerned with complex matter constructed from more elementary matter. ${ }^{22}$

Condillac acquired considerable prestige and influence in his own lifetime. His philosophical achievement was honoured not only by scientists and philosophes, but by various sections of government as well. From 1758 to 1767, Condillac was instructor to the Duke of Parma, nephew of Louis XV. Later, he turned down an opportunity to teach the three sons of the dauphin. A Cours d'etudes which he composed largely for the instruction of the Duke of Parma contained sections on grammar, the art of writing, the art of reasoning, the art of thinking, and a general history of man with a philosophy of history. In 1769, he received a place in the exclusive Académie Française. In 1777, the Polish government invited him to write an elementary logic for use in their public schools. This was, in fact, the source of his Logique, an outline of his ideological methods described for purposes of public instruction. It was treated as a model for education in French schools until shortly after the Revolution.

One of the first persons to become involved with Condillac's ideas and to publicize them was Jean le Rond d'Alembert (1717-83), an accomplished mathematician and physicist. He was one of the first Frenchmen to delve into the implications of Newtonian science and philosophy, and his Treatise on dynamics of 1744 is generally taken to be a landmark in Newtonian mechanics. He accepted, more or less as given, the sensationalist point of view which, for many, accompanied Newtonianism. It was d'Alembert who composed the "manifesto of the French Enlightenment" and its "discourse on method", the Preliminary discourse to the first volume of the Encyclopédie. ${ }^{23}$

${ }^{20}$ Ibid., pp. 12-22

${ }^{21}$ Knight analyses Condillac's 'Traité des sensations' in op. cit., note 7 above, pp. 52-78.

${ }^{22}$ Gusdorf, op. cit., note 3 above, pp. 232-249. Condillac's work and the question of language and scientific nomenclature are discussed by Moravia, op. cit., note 2 above.

${ }^{23}$ Schwab, 'Translator's introduction', Preliminary discourse, op. cit., note 4 above, pp. ix-xxxi. 


\section{Xavier Bichat}

Close friends since the 1740 s, d'Alembert and Condillac must have influenced one another's notions of scientific method and epistemology. Indeed, Condillac's influence on the Preliminary discourse is unmistakable. At the beginning of the work, d'Alembert asserted that "All our direct knowledge can be reduced to what we receive through our senses; whence it follows that we owe all our ideas to our sensations." He described how our sensations teach us, first, the fact of our existence and then, that of external objects in which he included our bodies. Differing somewhat from Condillac, however, d'Alembert described three faculties of the mind that react with the sensations - memory, which is the recalling of sensations; reason, which involves comparing; and imagination, which is the creation of new ideas.

D'Alembert also described the process of analysis, which he assumed produced seventeenth- and eighteenth-century mathematics and physics. ${ }^{24} \mathrm{He}$ discussed the process again in the article 'Analytique', which he composed for the first volume of the Encyclopédie. He wrote, in imitation of Newton, that the essence of scientific method is the path by means of which "one may proceed from composite substances to their elements, from motions to the forces which produce them, and in general, from effects to their causes, and from particular causes to more general ones, up to the point where one arrives to that which is the greatest of all."2s Through the Encyclopedie, Condillac's basic philosophy reached what was probably the widest audience possible at the time.

One of the first physicians to pay special attention to Condillac's texts was Felix Vicq d'Azyr (1748-94), who came to Paris from Normandy to study medicine in 1765. One of those enviable persons who is able to embrace a wide range of subjects and to enrich one by borrowing from another, he contributed substantially to contemporary discussions of anatomy, physiology, medical theory, and hygiene. Vicq d'Azyr tried consciously and consistently to apply Condillac's notions to his work and teaching. With analytical principles in mind, he developed the discipline of comparative anatomy by deliberately studying organs and functions in isolation, and then linking together as units. ${ }^{26}$ As permanent secretary of the Société Royale de la Médecine, he helped to make the most innovative French physicians conscious of sensationalist and analytic principles and of their potential application to a reform of medical teaching and practice.

On behalf of the Société Royale, Vicq d'Azyr presented certain reflections on medical teaching to the French National Assembly in 1790. The document was a powerful indictment of a profession which he described as populated with ignorant physicians and charlatans. In the entire country, he charged, there was no place where the principles of the healing art were adequately taught. Entry into medical schools was too easy, and once inside, the student received insufficient instruction and was

\footnotetext{
${ }^{24} \mathrm{~d}$ 'Alembert, op. cit., note 4 above, pp. 6-11.

${ }^{25}$ d'Alembert, 'Analytique', in Denis Diderot, Encyclopédie, 35 vols., Paris, 1751-80, vol. I, pp. 403-404.

${ }^{26}$ Vicq d'Azyr's work has not, thus far, been extensively studied. The most useful biography I have found is Jacques Moreau's 'Discours sur la vie et les ouvrages de Vicq d'Azyr', Oeuvres de Vicq d'Azyr, 6 vols., Paris, L. Duprat-Duverter, 1805, vol. 1, pp. 1-88. Vicq d'Azyr's general role in eighteenth-century French medicine is discussed by Moravia, op. cit., note 2 above. Moravia deals with Vicq d'Azyr's ideological convictions, his link to the Société Médicale d'Émulation, and his wish to see the medical profession develop autonomy.
} 


\section{Medicine and ideology}

subjected to inadequate examination. Medical theory in general, unable to free itself from its dependence upon other sciences, was unable to develop its own instruments, techniques, and laws. ${ }^{27}$ Vicq d'Azyr argued that medicine ought to define itself much more broadly, going beyond the mere examination of bodily parts and functions. Its preoccupations should also include psychology and even human social organization and its institutions. ${ }^{28}$ Vicq d'Azyr placed man at the summit of a chain of living beings and invited the philosopher, savant, artist, and literary man to join the physician and naturalist in studying him. ${ }^{29}$ Some of his notions were presented to the Revolutionary convention by Antoine Fourcroy shortly after Vicq d'Azyr's death. Thus he contributed towards the reformed education system which produced the Écoles de Santé in 1795.

Vicq d'Azyr's outspoken demand for autonomy and reform was not a new theme. It was implicit in the Montpellier physicians' reaction to iatromechanism and to the subordinate status of life sciences that it implied. Montpellier had considerably influenced Parisian intellectual life through such persons as Bordeu, Barthez, and Fouquet. ${ }^{30}$ By the time Vicq d'Azyr was writing, physiology had developed a language appropriate to its concerns. Addressing itself to sensibility and contractility, it no longer had to adopt an imagery of mechanics and of forces belonging to physics. It had a basis upon which to develop a mature and separate discipline. The vision of Vicq d'Azyr and the sensationalists incorporated more than physiological theory, however. It also had to do with medical practice, hygiene, and psychology, such that it was a broadly defined healing art secure in its status as an autonomous science and confident in its premisses. The scientific method of analysis and the sensationalist psychology upon which it was based had much to do, therefore, with the post-revolutionary changes in medical teaching and practice.

One salon in particular, that of Madame Helvétius at Auteuil near Paris, became an important centre for the elaboration of Condillac's principles. Before the Revolution, Madame Helvétius entertained such famous men as d'Holbach, Diderot, d'Alembert, Volney, Lavoisier, and the Americans, Jefferson and Franklin. Cabanis and Tracy, who belonged to a kind of third generation of philosophes, had certain of their ideas shaped by that company. For a time, the ideologues in general were considered to belong to an exclusive company of intellectuals who were able to contribute substantially to government and reform. They had tended to welcome the French Revolution initially, being generally interested in questions of politics, education, and so on. They generally agreed upon the necessity to create rational and free institutions to

\footnotetext{
${ }^{27}$ Felix Vicq d'Azyr, 'Reflexions sur les abus dans l'enseignement et l'exercise de la médecine', Oeuvres, op. cit., note 26 above, vol. 5, pp. 57-67. For a discussion of the general situation of the medical profession and the context in which Vicq d'Azyr's proposals were made, see Paul Delauney, Le monde médical Parisien au dix-huitième siècle, 2nd ed., Paris, Jules Rousset, 1906, especially pp. 21-27. Michel Foucault, The birth of the clinic, trans. by A. M. Sheridan, London, Tavistock, 1973, pp. 64-87, discusses the theme of a new medicine based upon the clinic and of Vicq d'Azyr's notion of hospital teaching as the solution to many of its problems.

${ }^{28}$ Vicq d'Azyr, 'Idée générale de là médecine et de ses différentes parties', Oeuvres, op. cit., note 26 above, vol. 5, pp. 44-57.

29 Vicq d'Azyr, 'Exposition des caractères qui distinguent les corps vivants', ibid., vol. 4, pp. 229-312.

${ }^{30}$ For a later statement of that position it is interesting to read Alexis Alquie, Précis de la doctrine médicale de l'École de Montpellier, 4th ed., Montpellier, Frères Ricard, 1846, especially pp. 27-102.
} 


\section{Xavier Bichat}

replace those of the rigid and anachronistic pre-revolutionary regime. In the 1790s, much was to change, and Auteuil became a refuge for certain liberal intellectuals who were repelled by the Terror and by the excesses of radical politics in general. And again, after 1801, it sheltered ideologues rejected by Napoleon and a newly reconstituted French establishment.

The systems of Locke and Condillac easily lent themselves to the liberal political philosophy with which the ideologues became identified. According to Condillac, as we have seen, much of an animal's development derives from its perception of sensations as being either pleasurable or uncomfortable, and from its striving after the one and the avoidance of the other. The pleasure-pain principle was extrapolated by some into political notions having to do with liberty and the basis of justice. If one is able to exercise one's will in conformity with a desire, one presumably possesses at least some measure of freedom. The pursuit of pleasure and the avoidance of pain can be and often were, in the eighteenth century, made the sole guides of moral judgement. Such an approach, presumably unencumbered by tradition, superstition, and habit, was judged to be more "natural" and hence closer to some kind of pristine human state. The intention of the ideologues who derived their political assumptions from psychological ones was to permit Frenchmen to create a moral and social order based upon utilitarian and materialistic notions of man and society. Education, they said, should be directed to that end and to the destruction of superstition and prejudice by the teaching of science. After the fall of Robespierre, many ideologues functioned as enthusiastic legislators and reformers of French institutions until 1801. That year, the motto "Dieu et l'Empereur" signalled the rise of Napoleon Bonaparte to undisputed power in France. As the motto suggested, a purely secular morality and the teachings of social utility were no longer to be countenanced. ${ }^{31}$ Napoleon turned against his former friends and supporters and even had them suspended from the Institute, thereby forcing them to form their centre of intellectual opposition at Auteuil.

One of the habitués of Auteuil as well as a refugee there after 1801 was AntoineLouis-Claude, Comte Destutt de Tracy (1754-1836), a philosopher and politician. Among his contemporaries, he came to be acknowledged as one of the most important of all the exponents of sensationalist philosophy. Under threat of the guillotine, Destutt de Tracy studied the sciences in Carmes prison, where he was thrown on charges of incisivism and aristocracy. His fellow-inmate Lavoisier introduced him to the works of Locke and Condillac. Named a senator in 1799 for his support of Napoleon's coup d'état, he went into a kind of exile in Auteuil in 1801, when he had time to put thoughts to paper.

Destutt de Tracy dreamed of creating an entire philosophical system that would include politics, economics, morals, ethics, language, and the sciences. As it was initially conceived, it was the first major effort to produce a theory of human psychology and epistemology tied to a study of the economic, social, and political forms of society. He labelled the all-embracing new science "ideology". But he abandoned

\footnotetext{
${ }^{31}$ Charles Hunter Van Duzer, Contributions of the ideologues to French revolutionary thought, Baltimore, Md., Johns Hopkins University Press, 1935, p. 14. For a discussion of the ideologues' education theories, see L. Pearce Williams, 'Science, education and the French Revolution', Isis, 1953, 44: 311-330.
} 


\section{Medicine and ideology}

the Elements d'idéologie when his friend Cabanis died, after completing sections on Grammaire générale, Logique, and Traité de volonté.

Destutt de Tracy claimed to be addressing young people "to make you see in detail what happens when you think, speak and reason." With the sort of purportedly rational zeal that sometimes afflicts persons preoccupied with science, he began by warning his readers to beware of those philosophers, "amiable enchanters but very dangerous seducers," who, like poets, reason according to their imagination and not after the facts. ${ }^{32}$ In asking the broad question, "What is thought?", Destutt de Tracy arrived at a system that differed somewhat from those of Locke and Condillac. Although he agreed that the first faculty of the body is sensation, he did not believe it to be the only one. Our thoughts are composed of the interaction of four elementary faculties. To sensation (I feel a burn) he added memory (it occurred yesterday); judgement (a body burned me); and will (I desired to remove myself from that body). Ingenious though it was, Condillac's imaginary statue was deemed unsuitable for explaining how a human being learns, simply because it lacked internal organs, receiving all its impressions from the exterior of the body. A living body, on the other hand, also experiences sensations of colic, nausea, hunger, pleasure, and pain. ${ }^{33}$

Like Condillac, Destutt de Tracy set out to examine rationally how one learns, composing complex ideas from simple ones. ${ }^{34}$ His approach reminds one often of that of his mentor. A significant addition to the development of sensationalism at the hands of Destutt de Tracy is an extended discussion of habit, which he considered to be basic to all learning. It is by means of habit that one learns to dance, to play a musical instrument, to read, and so on. It affects even memory and judgement. The more often something is experienced, the less one must consciously decompose its elements, and the less acutely one feels the sensations it produces. ${ }^{35}$ Again like Condillac, Destutt de Tracy considered language to be the primary and even the ultimate intellectual tool. It is the mechanism for all operations of thought, an analytical tool guiding human intelligence and permitting the expression of ideas. ${ }^{36}$

The ideologues' preoccupation with language can be illustrated from the work of Charles-Louis Dumas of Montpellier, who, in 1797, published his Systeme méthodique de nomenclature et classification des corps humains. He hoped to suggest how parts of the body might be named, preferably on the basis of their points of muscle attachment, so as to convey maximum information. Complicated and unwieldly, the result remained deservedly obscure. His more coherent and influential Principes de physiologie of 1801 opened with a statement on sensation and analysis, the 'General principles for the good philosophical method in the study of the sciences'. Although it reveals Condillac's almost inevitable influence, it also shows us that Dumas reverted to Locke's notions that ideas are the products of external sensations

\footnotetext{
${ }^{32}$ Antoine Louis Claude Destutt de Tracy, 'Idéologie proprement dite', Eléments d'idéologie, 3rd ed.,

Paris, Courcier, 1817, p. 19.

${ }^{33}$ Ibid., pp. 22-39.

${ }^{34}$ Ibid., pp. 78-92.

35 Ibid., pp. 274-294.

${ }^{36}$ Ibid., pp. 309-323. For more material on Tracy, see François Picavet, Les idéologues, Paris, Felix Alcan, 1891; Van Duzer, op. cit., note 31 above; and especially Emmett Kennedy, Destutt de Tracy and the origins of ideology, Mem. Amer. Phil. Soc., 1978, no. 129.
} 


\section{Xavier Bichat}

reacting with internal reflection. ${ }^{37}$

The philosophes largely scorned the European Middle Ages and tolerated the Renaissance only slightly better. Peter Gay has shown how deep was their veneration, however, for the pre-Christian civilizations of Greece and Rome, which most of them judged to have been genuinely progressive because they were free of religious superstition. ${ }^{38}$ Among those ideologues who were physicians, there was a particular flowering of interest in Hippocratic medicine. Because he lived a very long time ago and in a somewhat different scientific ethos, Hippocrates could be all things to all men. For centuries, he had been every physician's symbol of the ideal physician, as much as the interpretation of that ideal altered. He was important for the French vitalists, the members of the Société d'Émulation, and the ideologues in the eighteenth century because they took his work to be a model of good method. They frequently affirmed that Hippocrates was a great physician because he worked basically in the way his modern successors were advocating. He observed, he analysed, and he tried to understand an illness not merely in terms of its individual symptoms but in terms of the whole man and of the circumstances in which he found himself. To account for the state of health and for human temperament, for example, Hippocrates took serious account of such variables as age, sex, temperament, regimen, profession, and climate. ${ }^{39}$

Jean-Georges Cabanis (1757-1808), the ideologue physician par excellence, frequently referred to Hippocrates in his medical writings. At the age of ten, Cabanis attended the Collège de Brives, where he was taught by a man who tried consciously to apply the analytic method to the study of languages and grammar. After a disappointing flirtation with the Greek literary classics, Cabanis turned to medicine, qualifying as a physician at Rheims in 1784 . As early as 1778 , he began to attend the salon at Auteuil, where he became friends with Destutt de Tracy. Between 1785 and 1789, he lived there as a kind of adopted son of Madame Helvétius, and he inherited her home in 1800.40

He demonstrates well the relationship between sensationalism, medicine, and the science of man. His first major work, Degré de la certitude de la médecine, 1788, examined the question of what is good scientific method in medicine. To acquire knowledge about life, death, and illness, he argued, it is sufficient to observe and to examine sensible phenomena and their interconnexion. While it is the observer's duty to study carefully events and their connexions, he must remember that the principles of life, the ultimate nature and cause of disease, and the nature of healing substances are all secrets beyond the capacity of researchers. One must remain within the limits of sensory phenomena. That was not to deny the possibility of medicine's becoming a rigorous science. It was, however, to deny the validity of systems and of a priori principles.

\footnotetext{
${ }^{37}$ Charles Louis Dumas, Principes de physiologie, 4 vols., Paris, Deterville, 1800-04, vol. I, pp. 8-9.

${ }^{38}$ This is the theme of Peter Gay's The Enlightenment, an interpretation, New York, Vintage, 1968.

${ }^{39}$ Moravia, op. cit., note 2 above, pp. 1098-1105.

${ }^{40}$ Biographical details are available in Claude Lehec's 'Biographie', Oeuvres philosophiques de P. J. G. Cabanis, ed. by Claude Lehec and Jean Cazeneuve, 2 vols., Paris, Presses Universitaires, 1956, vol. 1, pp. $v-x x i$; and in Picavet, op. cit., note 36 above, pp. 176-224.
} 


\section{Medicine and ideology}

Cabanis' thoughts on the subject of analysis or scientific method as it applied to medicine were expounded further in his Coup d'oeil sur les révolutions et sur la réforme de la médecine, 1804. The years between its writing and that of the Certitude de la médecine were largely taken up with politics. A firm believer in liberal reform, Cabanis joined public life after the execution of Robespierre. He sat on the Hospital Commission after the re-establishment of medical education; he was appointed Professor of Hygiene and Clinical Medicine in Paris; and he became a member of the National Institute and was made a representative on the Council of Five Hundred. Like Destutt de Tracy, he was named a senator as a reward for his support of Napoleon's coup d'état in 1799. In 1804, however, he was deprived of membership in the National Institute and the Senate, and he retired to Auteuil to write.

In Révolutions et réforme, Cabanis discussed his ambiguous feelings toward the profession of medicine. It was currently like a traveller hindered with excess baggage, which represented the great weight of material collected without judgement or discrimination. In spite of medicine's dismal past, however, its potential was enormous, if men would but undertake to be governed by reason. ${ }^{41}$ The Greeks, of whom Cabanis wrote in superlatives, were taken to be an appropriate model. Hippocrates, he alleged, had delivered medicine from false systems and had created new methods for it. The analytic method is basically Hippocratic procedure recently rediscovered. ${ }^{42}$ Francis Bacon was the first modern man to acknowledge the supreme importance of sensory evidence. Thereafter, many persons including Hobbes, Locke, Bonnet, and especially Condillac had progressively refined the process of philosophical analysis, making it surer and simpler. ${ }^{43}$

Cabanis' description of analysis was much like that offered by Dumas in his Principes de physiologie. Both men were influenced by the Baconian inductive method, which they fused on to sensationalism. Cabanis distinguished four basic types of analysis. An analysis of description examines a body's size, shape, form, and the relation of the parts. An analysis of decomposition or recomposition is involved, for example, in trying to discover the workings of a watch by taking it apart and reassembling it. This was presumably the method that Lavoisier and Bichat employed to do their chemical work and tissue work respectively. A historic analysis is an examination of how phenomena succeed one another. It is suitable for understanding plant growth, muscular action, or the progress of an illness. It was, in fact, Hippocrates' method for observing disease. Finally, the analysis of deduction considers the ideas we receive from objects rather more than the mere objects themselves. With it, one can compare ideas, determine their interconnexions and thereby deduce a new series of truths. By a series of transformations, one can arrive at some primary ideas that cannot be verified by experiment. For example, the deduction that the sun will rise tomorrow belongs in this category. So does the analysis of drugs and the determination of their effectiveness. ${ }^{44}$ Such was Cabanis' faith in sound

\footnotetext{
${ }^{4}$ Pierre Jean Georges Cabanis, Coup d'oeil sur les révolutions et sur la réforme de la médecine, Paris, Crapart, Caille et Ravier, 1804, pp. 3-35.

${ }^{42}$ Ibid., pp. 72-97. See also Pierre Jean Georges Cabanis, Rapports du physique et du moral de l'homme, 2 vols., Paris, Bechet Jeune, 1824, vol, 1, pp. 11-36.

${ }^{43}$ Cabanis, op. cit., note 41 above, pp. 145-194.

44 Ibid., pp. 270-313.
} 
method that he believed that twenty-five or thirty years of reorganizing and reclassifying the facts would suffice to verify all observations except perhaps those having to do with epidemics.

Cabanis' principal work was his Rapports du physique et du moral de l'homme, which appeared in 1805. It dealt with questions of human consciousness and learning and has led people to describe the author as a precursor or even the founder of psychosomatic medicine. ${ }^{45}$ Whether or not one accepts so enthusiastic an evaluation, the work was Cabanis' particular contribution to the goal of a unified science of man. Human nature, he claimed, must be studied as a composite of man's physical and moral make-up. Medical science must, henceforth, take into account man's physical, cultural, and social milieu, as well as the condition of his physical body. Environment invariably affects the condition of a body, the type of illness to which it is subject, and its reactions to medication and other treatment. To be totally effective, the physician must also be a moralist - we might say a psychologist - who seeks to perfect the private life, a legislator who tries to correct a national or social situation, and a healer of the various problems that affect man's wellbeing in general. Cabanis' political involvement, therefore, was entirely consistent with medical practice.

The notions expounded in Du physique et moral were grounded in sensationalism. Life, Cabanis wrote, consists in a series of movements or activities executed in response to the impressions received by various organs. Without our senses, we in effect would not exist as living beings, for to live is to feel or to sense. ${ }^{46}$ Indeed, Cabanis described birth as not merely a change but a completely new life for the animal. A foetus possesses only the sense of touch, because that alone can be of some small use to it. Only when it leaves the womb, however, does it begin to develop sight, taste, smell, and hearing, and thus to live its full sensory life.

Like Destutt de Tracy, Cabanis found Condillac's statue-man to be too limited to describe learning adequately. Although the effects of sensations in the animal are primary, they are modified by such variables as age, temperament, health, climate, and regimen. Some of these factors are external in origin, while others are purely internal. Habitual ideas and feelings are often altered by factors that have nothing to do with external sensations. Puberty provides us with perhaps the best example of a major series of such changes. Perhaps less dramatically, even the digestive organs, the heart, and the great vessels can have profound effects upon us. In spite of his affirmations of loyalty to Condillac and to Locke, Cabanis found it necessary to reintroduce at least some innate principles into the body. It is necessary, he believed, to postulate an instinctive life that coexists with the sensory life to account for certain unlearned visceral phenomena. This innate life was not, however, capable of accounting for such phenomena as the human religious sense. Indeed, according to Cabanis, it is absolutely unintelligent, only touching the conscious mind at the level of strong emotions and responses. Unlike Condillac's theory, it can account for sexual instincts, a maternal sense, and for such instinctive activity as nest-building among birds, as well

\footnotetext{
45 Pierre Astruc, 'Les idées de Cabanis sur la médecine', Le progrès médicale, 1956, 84: 372-374.

${ }^{46}$ Cabanis, op. cit., note 42 above, vol. 1, pp. 36-42.
} 


\section{Medicine and ideology}

as for all other activities which have nothing to do with habit or judgement. ${ }^{47}$

The reader will recognize here a variant on Grimaud's and Bichat's separation of an animal's life into external and internal categories. Whether consciously or not, Cabanis was here echoing Bichat's contention, developed some four years earlier in $L a$ vie et la mort, that birth is the beginning of an external life which derives from conscious sensations. In the shelter of the womb, Bichat said, only internal or organic functions can exist. In that condition, an animal's consciousness and intelligence cannot develop, so that a foetus is little more than a kind of a plant. ${ }^{48}$

Cabanis' notions of sensationalism and psychology had important social implications. As long as one assumes that all human beings receive the same impressions from the external world through sensory organs which behave in a consistent way, one may believe in the possibility of achieving human equality. Its possibility, in fact, seems to be implied in Condillac's viewpoint. According to Cabanis, however, people vary widely not only as a result of their environment, but also because of such factors as age, sex, state of health, and so on. Indeed, they are born neither physiologically, temperamentally, nor intellectually equal, making it impossible for them to learn and develop in similar ways. ${ }^{49}$

This preoccupation with man as a complex amalgam of mind and body shaped by physical, psychological, and environmental factors received considerable attention in the eighteenth century. Hippocrates had probably pointed the way to this type of study in On airs, waters and places, an analysis of the effects of weather, climate, the seasons, and the landscape on human temperament and health. ${ }^{50}$ In his Esprit des lois, Montesquieu was searching for the laws that govern human organization. He observed that the general character of people differs substantially in various climates. The second volume of Barthez' Elements de la science de l'homme included a study of temperaments and an analysis of the effect of social and geographical factors on the development of man's physical and moral natures. He contended that climate, terrain, altitude, distance from the sea, winds, and the qualities of the sun affect human personality and behaviour. Even political factors alter the vital principle and consequently man's physical, mental, and moral make-up. Such studies were entirely consistent with the striving for an autonomous science of man to which the Société

${ }^{47}$ Ibid., vol. 1, pp. 91-121; vol. 2, pp. 319-328; Jean Cazeneuve, 'Philosophie de Cabanis', Oeuvres philosophiques, op. cit., note 40 above, vol. 1, pp. xxv-xxix; Picavet, op. cit., note 36 above, pp. 259-263.

48 Jean Charles Grimaud, Mémoire sur la nutrition, Montpellier, Jean Martel, 1787, pp. 19-40; Cours complet de physiologie, 2 vols., 2nd ed., Paris, Egron, Gabon, Crochard, l'Heureux, Bechet et Lanthois, 1824, vol. 1, pp. 38-39; Xavier Bichat, Recherches physiologiques sur la vie et la mort, Paris, Brosson, Gabon, 1800, Art. 1, 1-9.

49 This point was made by Frank E. Manuel, 'From equality to organicism', J. Hist. Ideas, 1956, 17: 54-69. The difference between the notions of Condillac and of Cabanis led Aram Vartanian in the critical edition of la Mettrie's L'homme machine, Princeton University Press, 1960, pp. 125-129, to argue strenuously that, unlike Tracy, Cabanis was an opponent of Condillac's system. I believe that, though Cabanis moved a considerable distance from the older system, he did not break with it. Significantly, he remained in substantial agreement about the primary role of the sensations in the intellectual life, and he was an exponent of the system of analysis. Beyond this, however, the question is merely a quibble over categories.

so 'Traité des airs, des eaux et des lieux', in Oeuvres complètes d'Hippocrate, ed. and trans. by E. Littré, 10 vols., Paris, Baillière, 1840, vol. 2, pp. 12-93. Eng. trans. in G. E. R. Lloyd (editor), Hippocratic writings, Harmondsworth, Middx., Penguin Books, 1978, pp. 148-169. 


\section{Xavier Bichat}

Royale de Médecine and the Société d'Émulation had aspired. There was a commonly held conviction that morality, religion, the formation of societies, and so on would in time be shown to be on a par with physical laws and hence amenable to analysis. ${ }^{31}$

One of the most famous quotations in the history of medicine is that in which Cabanis described the brain as "a particular organ especially destined to produce [thought]; just as the stomach and the intestines operate the digestion; the liver filters the bile; the parotids and the maxillary and sublingual glands prepare the salivary juices." Sensory impressions entering the brain, he continued, induce it to action just as the sensation of food entering the stomach excites more abundant secretions of gastric juice. "The proper function of the one is to perceive each particular impression, to attach signs to it, to combine different impressions, to make comparisons between them, to take judgements and resolutions from them, just as the function of the other is to act on nutritive substances." 32 His more pious critics were outraged at what appeared to be an atheistic point of view. During the Bourbon Restoration, such statements provided a convenient excuse to dismiss and discredit Cabanis' work, causing it to fade into relative obscurity. It is incorrect, however, to accept so trivial and superficial an interpretation of Cabanis' words and thereby to dismiss him as a crude mechanist.

He was a materialist who, like La Mettrie and Diderot, proceeded from deeply rooted vitalist convictions. He shared their monist assumptions whereby the universe is a material unity. ${ }^{33}$ Like them, Cabanis saw the world as a kind of nest of spontaneous, ubiquitous activity. Under certain conditions of organization, brute matter is transformed into living substance which is able to experience conscious or unconscious sensation. Matter possesses its own internal and spontaneous activity, which Cabanis attributed to a single universal force that is variously manifest in different forms of organization. It ranges from simple gravitation, to "electrical affinities", to "instinct of plants", and finally, to the complex nervous sensibility of animals. ${ }^{34}$ The latter, he believed cannot be explained in terms of physical and chemical hypotheses but only in terms of the living body itself. One is reminded here of Barthez' hierarchy of natural motive forces ranging from attraction through to the forces of the vital principle.

Like all good scientific men by then, Cabanis ignored the question of first causes or "essences" in nature. He did not even refer to the soul as an intellectual principle. Nor did he make any reference to a creator God who transcended his creation. He is more accurately described as a pantheist or a deist than an atheist, for he believed that the

${ }^{51}$ Gusdorf, op. cit., note 3 above, pp. 180-212.

32 Cabanis, op. cit., note 42 above, vol. 1, pp. 77-133.

s3 Ibid., pp. 263-293.

${ }^{54}$ See Martin S. Staum, Medical components of Cabanis' science of man, Princton University Press, 1981. Staum discusses Cabanis' debt to the animists and vitalists. He objects to the "materialist" label traditionally applied to Cabanis, who was by no means a mechanist reductionist. His phraseology resembled that of notorious atheists like d'Holbach and La Mettrie, says Staum, but he was very interested in the question of vital properties and human intelligence. See also Paul Delauney, 'L'évolution philosophique et médicale de biomechanicisme de Descartes à Boerhaave, de Leibniz à Cabanis', Le progrès médicale, 1927, 20: 1289-1384; and Owsei Temkin, 'The philosophical background of Magendie's physiology', Bull. Hist. Med., 1946, 20: 10-35. 


\section{Medicine and ideology}

world is inhabited by an intelligent and providential will. ${ }^{5 s}$ The human mind was presumed to participate in this universal intelligence. Such a monist notion wedded to the sensationalist belief that the development of a system of morals is based solely on responses to pleasure and to pain make reference to a deity unnecessary, at least for scientific purposes.

One of the clearest examples of the specific application of an analytic method to a medical question is the work on pathological classification done by Philippe Pinel (1745-1827), who exerted a major influence on Bichat. Pinel received a medical degree from Toulouse in 1773 before going to Montpellier. In 1777, being too poor to hire transport, he walked to Paris. There, he became a friend of Lavoisier and so came under the general influence of the ideologues. He began to study Locke and Condillac. Cabanis introduced him to the salon of Madame Helvétius. In 1792, on the recommendation of the Hospital Commission on which Cabanis sat, the painfully shy Pinel was appointed to take charge of the insane patients at the Hôpital Générale, established in 1656 to clear Paris of beggars. Its two major divisions were the Bicêtre, which confined males, and the Saltpêtrière, which was primarily for women. His much publicized move of releasing the patients, veritable prisoners, from their chains is reported to have saved his life on one occasion, when rumours that doctors were poisoning wells led to Pinel's seizure by a mob. He was rescued by a member of the French Guards, a former inmate who had been unchained.

As a habitue of the ideologues' groups, Pinel imbibed the arguments concerning the need to develop an autonomous science of medicine. It was assumed that the reform would include development of a rational and systematic nosology, or classification and description of disease. Vicq d'Azyr and other members of the Société Royale de Médecine had emphasized the need for such. As if to fill the need, Pinel's Nosographie philosophique appeared in 1798..$^{36}$ To do the work, he methodically applied the analytic method to decompose complex pathological states with a view to isolating the elements common to specific morbid phenomena. Mere observation of illness would not have been sufficient. According to Pinel, such classifications as those of Sauvages and William Cullen were too laborious, relying overmuch on such systems as Linnaeus' botanical classification. They failed to sort out the fundamental symptoms of a disease from its multitude of individual variations. Because there was frequent confusion between basic and secondary affections, there was an excessive and confusing multiplication of symptoms and illnesses. Pinel asfumed that an illness was a sort of entity with a certain degree of regularity, a constancy of cause, effect, and consequences. By means of analysis, he intended to sort out and to isolate essential component parts of a disease from accidental individual symptoms. ${ }^{57}$

In a section on 'Method', Pinel advised the nosographer and the physician that the first step in studying an illness is to note the age and constitution of the individual, to retrace the disease's symptoms and to note the pulse, temperature, respiration, diges-

\footnotetext{
ss See Cazeneuve, loc. cit., note 47 above, pp. xxxv-xxxvii.

56 Pinel's Nosographie philosophique and its relationship to earlier classification systems and to ideology are discussed by Moravia, op. cit., note 2 above.

s7 Philippe Pinel, 'Introduction', Nosographie philosophique ou la méthode de l'analyse appliquée à la médecine, 2 vols., Paris, Richard, Caille et Ravier, 1798, vol. 1, pp. iv-xxxix.
} 


\section{Xavier Bichat}

tion, intellectual faculties, and excretions. One must not ignore such extenuating circumstances as fatigue, moral affections, abuse of pleasure, unhealthy air, contagious principles, and so on. Symptoms must be examined "independently of all hypotheses and only in terms of impressions made in the sensory organs." The second step requires the observer to separate individual variations of an illness from its specific characteristics. Finally, one must consider particular affections in relation to age, sex, manner of living, and habits which might modify the progress of an illness. ${ }^{58}$

Pinel divided disease into six classes: fevers, inflammations (phlegmasies), active haemorrhaging, nervous diseases, lymphatic affections, and "others". These were subdivided into orders, genera, and finally, a multitude of species. He consciously applied Condillac's method throughout. "It is necessary in the exposition as in the research for truth", he wrote "to begin with the most simple ideas and the ones which come immediately from the senses and then to move by degree to the most complex ideas."

Pinel arrived at six categories of fevers, which seemed to him to embrace all the known types: angiotenic fevers are characterized by an irritation of blood vessels; meningogastric fevers have their seat in the stomach membranes or in the membrane of the duodenum; adenomeningeal fevers shown an irritation of mucous membranes; adynamic fevers involve atony of muscle fibres; ataxic fevers follow a physical or moral shock to the nerves and finally, adenonervous fevers involve a contagious principle that affects nerves and glands. ${ }^{59}$

Inflammation, the second class of illness, includes a variety of contagious diseases. Ophthalmia, tonsillitis, various sorts of sore throat, and numerous catarrhs are all inflammations of mucous membranes; encephalitis, pleurisy, and peritonitis are inflammations of diaphanous membranes; "phlegmon", hepatitis, nephritis, and peripneumonia are irritations of cellular tissue glands, and the visceral parenchyma; rheumatism and gout are of the order of muscle inflammations; and finally, malignant pustules, skin inflammations, smallpox, measles, and scarlet fever are part of the order of cutaneous inflammations. ${ }^{60}$ And so on with the remaining four classes of illness.

I list these categories only to make the point that in each case, the affected part was taken to be a particular fibre or member rather than a particular organ. Angiotenic fever, for example, does not attack the whole blood vessel but rather its tunic; inflammations are located in particular membranes rather than in the lungs, stomach, or other organs. It was an important innovation in pathological classification. It was also a catalyst for Bichat, leading him to differentiate the various membranes of the animal anatomy and to study their distribution and properties. In what was rather an uncharacteristic gesture for him, Bichat acknowledged Pinel to be the source of his ideas in the Traite des membranes, justifiably hastening to add that many of the

\footnotetext{
s8 Ibid., vol. 2, pp. 374-380; see also the 2nd ed., 3 vols., Paris, J. A. Brosson, 1803, vol. 3, pp. 523-530, where discussion is more extensive.

39 Ibid., Ist ed., vol. 1, pp. 1-129, and 2nd ed., vol. 1, are devoted to a discussion of 'Fièvres'.

${ }^{60}$ Ibid., Ist ed., vol. 1, pp. 130-240, and 2nd ed., vol. 2, pp. 1-450, are devoted to a discussion of 'Phlegmasies' or inflammation.
} 


\title{
Medicine and ideology
}

specific results were entirely his own. ${ }^{61}$

Pinel, in turn, was quick to appreciate the importance of Bichat's theoretical innovation. In the second edition of the Nosographie in 1802, he commended Bichat's work calling it a most scrupulous and attentive examination of the subject. ${ }^{62}$ By then, of course, the Anatomie générale had superseded the Traité des membranes. Although Pinel's first and second editions are the same for the most part, it is clear that his thoughts concerning his classification were affected by what Bichat had written. The implications of his own classification were thereby enhanced. Pinel wrote the following in 1802:

\begin{abstract}
The general view of all the theories of inflammation regard this term as unequivocal and as representing the same series of symptoms in all cases; whereas it may be taken with different senses depending upon whether it is located in the tegumens, the cellular tissue, the viscera, serous membranes, the articulation or the mucous membranes. But in these parts, so different amongst themselves, when one compares them for tissue, structure, sensibility and organic functions, do they not still have a common conformity in the lesions which they experience due to an irritating cause; and cannot one observe there the development, although in different degrees and in various proportions, the heat, the redness, the tension and the discomfort whose ensemble is indicated by the abstract terms inflammation?
\end{abstract}

The statement, which is not present in the first edition, indicates that Pinel had a fairly substantial involvement with the theory and the methods that Bichat used to study the tissues. Pinel wrote that he intended to combine the views of Haller, Bichat, and other modern physiologists to throw new light on the true character and the seat of cutaneous inflammations. He described the particularly effective method of isolating the epidermis by maceration. One can only detach the epidermis of a cadaver, he wrote, by means of putrefaction, maceration, or boiling. ${ }^{63}$ This was precisely the sort of method which Bichat reported using to distinguish between membranes and then, subsequently, all the twenty-one tissues into which he divided the bodily parts.

The ideologues' range of interests was wide enough, as we have seen, to include all the natural sciences as well as man's political and social environment. During the

\footnotetext{
${ }^{61}$ Xavier Bichat, 'Dissertation sur les membranes, et sur leurs rapports généraux d'organisation', Mémoires de la Société Médicale d'Émulation, 1798, 2: 371-385; and Xavier Bichat, Traité des membranes en général et de diverses membranes en particulier, Paris, Richard, Caille et Ravier, 1800, pp. 3-5. An instructive and interesting insight into Pinel's classification, and especially of its relationship with that of Bichat, is provided by Foucault, op. cit., note 27 above, esp. pp. 174-194. He makes the point that there is a great gulf between their two methods, for with Bichat, disease was no longer a particular entity but a complex movement of tissues in reaction to an irritating cause. For Pinel, fever was essential. For Bichat, it is a local irritation, an increase in the flow of blood accompanied by circulation.

${ }^{62}$ Pinel, op. cit., note 58 above, 2nd ed., vol. 1, pp. i-lvi, esp. xxxiii-xxxiv.

${ }^{63}$ Ibid., pp. 17-19. The connexion between Pinel's and Bichat's classification is even more clearly stated in a quotation in the 5th ed. of Nosographie philosophique, which is quoted by Pedro Lain Entralgo, 'Sensualism and vitalism in Bichat's "Anatomie Générale"', J. Hist. Med., 1948, 3: 57-58: "The inflammatory state has, in fact, properties in common whatever the part attacked may be, and these points of contact are more considerable in proportion to the closeness of the analogy of the tissues and the organic functions of the parts affected; but again, how great is the diversity, if the organization of these parts is different! The phlegmasies have thus been divided into different orders, according as they are found in the integuments, in the mucous membranes, serous, fibrous, in the glands, or in the muscles. What does it matter that the arachnoid membrane, the pleura and the peritoneum are situated in the different parts of the human body, if these membranes possess general conformities in their structure?" With this quotation, Lain Entralgo implied that Pinel had a distinctly articulated tissue theory before Bichat published his work on membranes and tissues. Unfortunately, this statement is not present in the first or even the second edition of Nosographie philosophique. I believe that it reinforces the point that Bichat and Pinel mutually profited from each other's ideas.
} 


\section{Xavier Bichat}

eighteenth century, what were considered to be Newtonian scientific principles had been extended by a variety of enthusiasts to embrace the study of the human mind, society, and even theology. The ideologues had a hand in such developments. Because Napoleon suppressed the ideologues' teachings, however, the influence of sensationalism and analysis in the nineteenth century was only indirect. Certain deeply rooted notions concerning the nature of scientific investigation necessarily became implicit and thus remained part of the stock-in-trade of the scientific community. Temkin has shown, for example, that François Magendie was firmly rooted in the sensationalist tradition and in the vitalist assumptions that accompanied it. ${ }^{64}$ Furthermore, the social sciences took form in the last century, building upon earlier foundations. Thanks at least partly to the preoccupations of the ideologues, sociology, political science, and above all psychology now had a rationale for their status as "sciences". This ostensibly put them on a par with physics, chemistry, and physiology. The names of Condillac, Destutt de Tracy, and Cabanis, however, largely vanished from the literature of intellectual history only to be restored in recent years.

We shall see in the next three chapters that sensationalist assumptions played a major role in Bichat's work. He belonged to the ideologues at least peripherally. Without being particularly careful to relate his ideas to those of anyone other than Pinel, Bichat described learning as a process of acquiring and relating sensations. The very idea of two lives upon which the arguments of La vie et la mort rested was possible only if one accepted such an epistemology. His much-lauded Anatomie générale is a classic example of a deliberate application of the method of analysis. Bichat decomposed the complex body parts and organs so as to isolate and to study the simple tissues composing them, and only his untimely death interrupted the recomposition he was undertaking in the Anatomie descriptive.

\footnotetext{
${ }^{64}$ Temkin, op. cit., note 54 above, pp. 20-35.
} 